Ivana Prokic

UDC: 004.031.42:371.3

Tehnička škola "Ub"

DOI: 10.18485/dh.2015.2.ch17

\title{
NAČINI POBOLJŠANJA NASTAVE POMOĆU DIGITALNIH HUMANISTIČKIH NAUKA
}

\begin{abstract}
Sažetak
Cilj ovog rada je da pokaže značaj pedagogije u oblasti digitalnih humanističkih nauka. Postoje različite metode koje nastavnici mogu da koriste u cilju razvijanja vokabulara kod učenika koristeći nove tehnologije. Vizuelizacijom učenici mogu lakše da dodju do rešenja i da pogode značenje reči, a nastavnik im daje uputstva. Počela sam da primenjujem ovu ideju u praksi nakon vežbe na Eltinom seminaru. Prema Pijažeu (1958), procesi asimilacije i akomodacije zahtevaju aktivno učenje, a ne pasivno, jer se veštine rešavanja problema ne mogu naučiti, one se moraju otkriti. Dečije znanje na taj način postaje trajno. Najpre sam ocenjivala znanje I spremnost učenika za usvajanje novog vokabulara standardizovanim testovima koji mere stručnost i dostignuća na engleskom jeziku, obraćajući pažnju na njihovu efikasnost u bilo kom trenutku procesa učenja. Primetila sam da ne pokazuju toliko interesovanje za moja uputstva kao u prethodnom periodu. Pala im je motivacija, I kao da da je ovo novi jezik, koji je previše težak za učenje. Neki imaju poteškoća u svakom segmentu učenja jezika, čitanja, izgovora, vokabulara, gramatike i razumevanja procitanog I izgovorenog. Pomoću digitalnih humanističkih nauka, ovaj problem može biti uspešno rešen, ali je potrebno neko vreme. Ova ideja mi je sinula kada sam primetila se kod nekih učenika pojavio Plato efekat. Postepeno sam počela da uvodim različite teme, od kulture, sporta, istorije, filmova do literature. Dakle, kako možemo da postignemo uspeh na ovom polju?! Pošto živimo u 21. veku, učenici imaju pametne telefone, koji se mogu koristiti za učenje novih reči, pronalaženje korisnih informacija na Internetu, itd. Oni mogu da postanu motivisaniji prilikom usvajanja drugog jezika.
\end{abstract}

Ključne reči: Pedagogija, digitalne humanističke nauke, vizuelizacija, Plato efekat, usvajanje novog vokabulara, usvajanje drugog jezika

According to many psychologists, there are four basic levels of learning.

1. Rote

2. Understanding 


\section{Application}

4. Correlation

\section{Rote -}

The memorization of $500^{\prime}$ rate of decent on a turn to base is the lowest level of learning.

\section{Understanding -}

Understanding that the helicopter has to descend down from pattern altitude to land brings the learning experience up to the level of understanding.

\section{Application -}

The student is now able to start a decent down to the surface without the instructor telling him its time, because the student not only understands the maneuver but knows when to put the understood information into use.

\section{Correlation -}

The student is able to take this application of when to start a decent in the traffic pattern and apply it not only to the traffic pattern but also in real life scenarios.

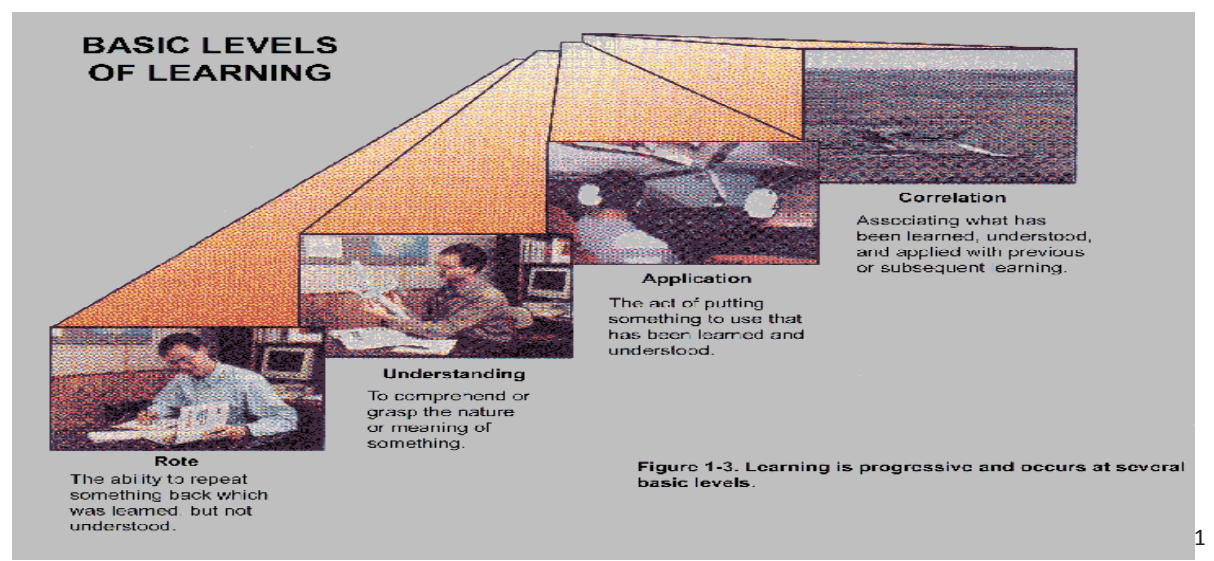

1 Retrieved on August 20, 2015 from https://www.google.com/search?q=basic+levels+of +learning\&espv $=2 \& b i w=1366 \& b i h=633 \&$ source $=$ Inms \&tbm $=i s c h \& s a=X \& v e d=0 a h U K E w i$ Pg_imm_jMAhXF0xQKHWOIC28Q_AUIBigB\#imgrc=3hq9aXaAlp42bM\%3A 


\section{Bloom's Taxonomy's 6 Levels of Learning}

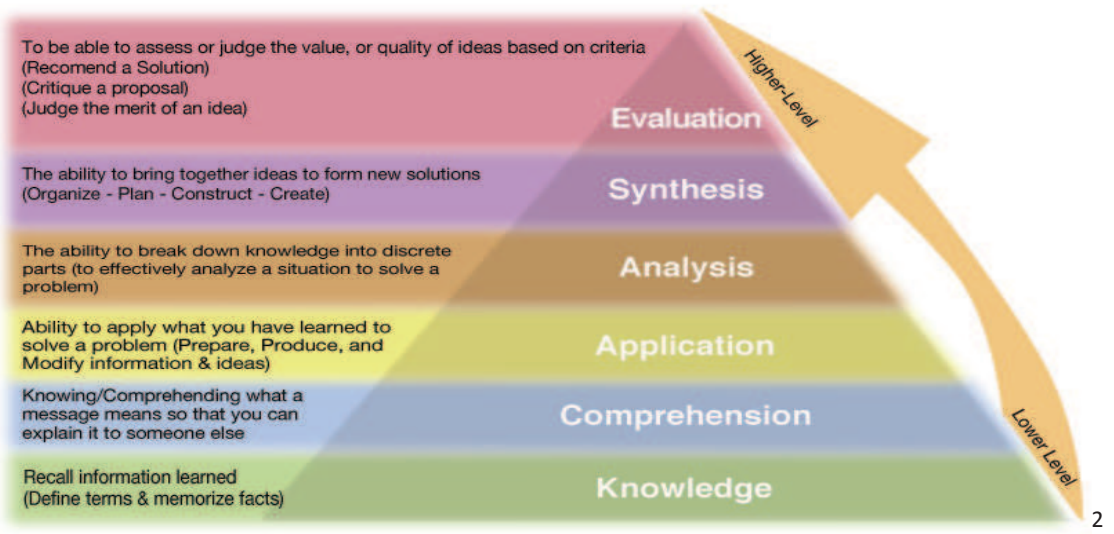

According to Bloom, there are six levels of learning. A teacher must teach a student how to think actively and to activate a student to develop creative and critical thinking, then to motivate him. A student must possess knowledge of a certain topic.

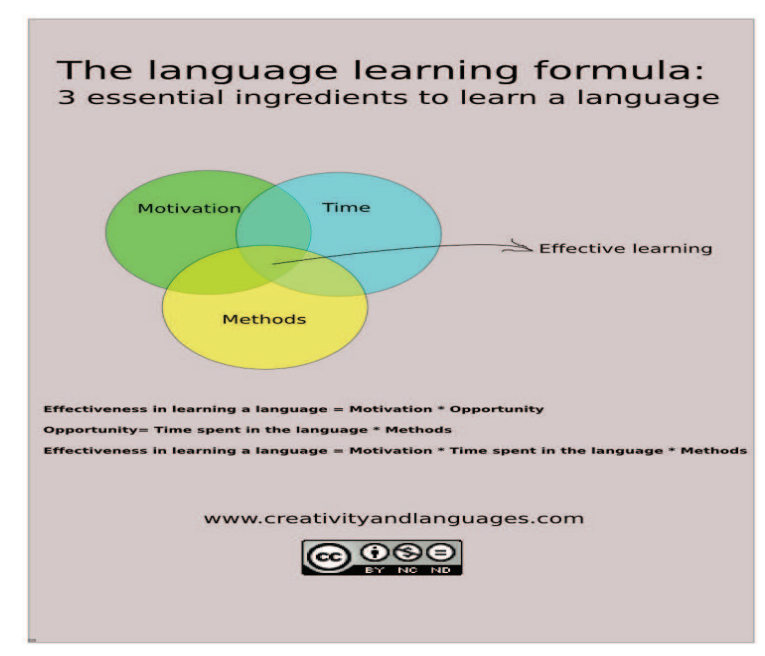

2 Retrieved on August 20, 2015 from https://www.google.com/search?q=bloom\%27s+tax onomy\&espv=2\&biw=1366\&bih=633\&source=Inms\&tbm=isch\&sa=X\&ved=0ahUKEwj0mr bFrPjMAhVBaxQKHXOjChwQ_AUIBygC\#tbm=isch\&q=bloom\%27s+taxonomy+six+levels\&i mgrc=jrz2itWcLKSADM\%3A 
The language learning formula includes three essential ingredients to learn a language: motivation, time, methods. The field where these key factors overlap is where effective learning happens. In my opinion, another motivational factor for the second language acquisition can be the culture of a new language.

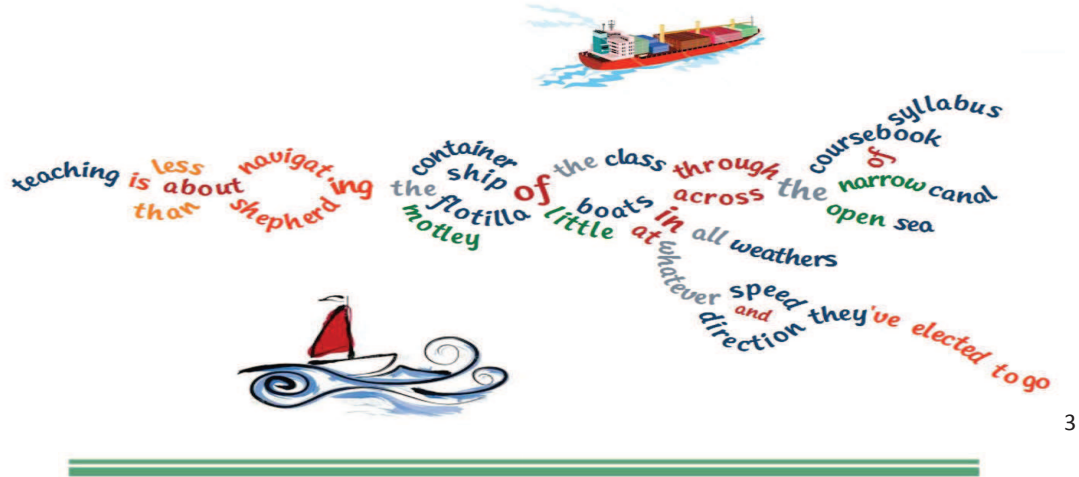

Main difficulty experienced when learning a new langunge

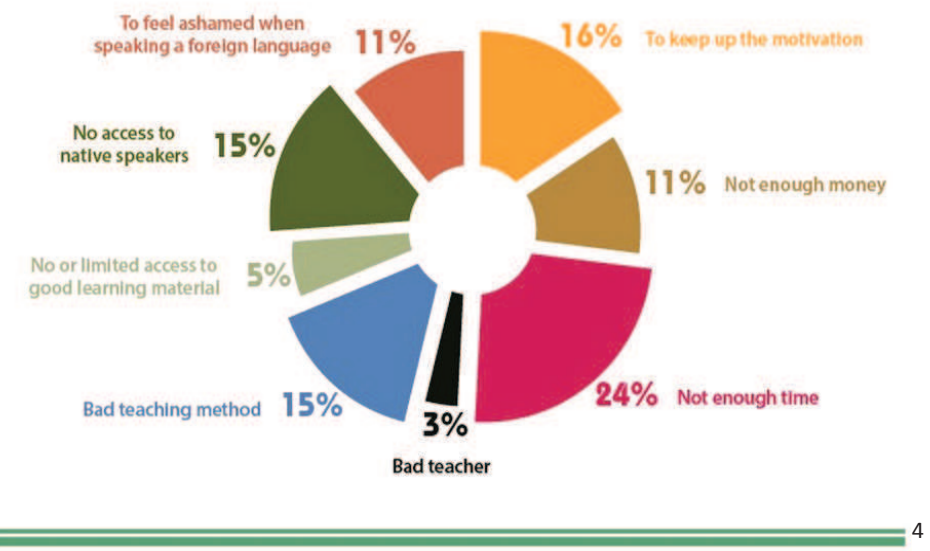

3 https://www.google.com/search?q=language+garden+makes+learning\&espv=2\&biw $=1366 \& b i h=633 \&$ source $=$ Inms\&tbm=isch\&sa=X\&ved=0ahUKEwjn4c-KsPjMAhXIvRQ KHedEAPIQ_AUIBigB\#imgrc=Rfw6zfny_vR5NM\%3A

4 https://www.google.com/search?q=basic+levels+of+learning\&espv=2\&biw=1366\&bih=6 33\&source=Inms\&tbm=isch\&sa=X\&ved=0ahUKEwiOn4SsrPjMAhXDPxQKHZDWDiwQ_AU IBigB\#tbm=isch\&q=main+difficulties+when++learning+a+language\&imgrc=Ux8m7Jr4b_ iB8M\%3A 
All these reasons may contribute that a learner reaches a learner plateau.

A learning plateau is a term that is often used in educational psychology. This is a kind of phenomenon that refers to a situation when the learner in the course of learning, despite all the efforts of learning and practice, seems to make no significant progress. In the beginning of the process, the learning curve is steep, then it gradually starts leveling out. The learning plateau is that flat part of learning curve which comes after rapid progress initially. However, after being in plateau for certain period, the learner will continue to make progress.

The plateau period is sometimes also referred as the "Temporary Fossilization," which is a prelude to permanent fossilization. Fossilization means the rules and linguistic items of the native language of the speaker persist in the inter-language relative to a target language. When compared to fossilization, the plateau is the temporary and reversible stage of language learning.
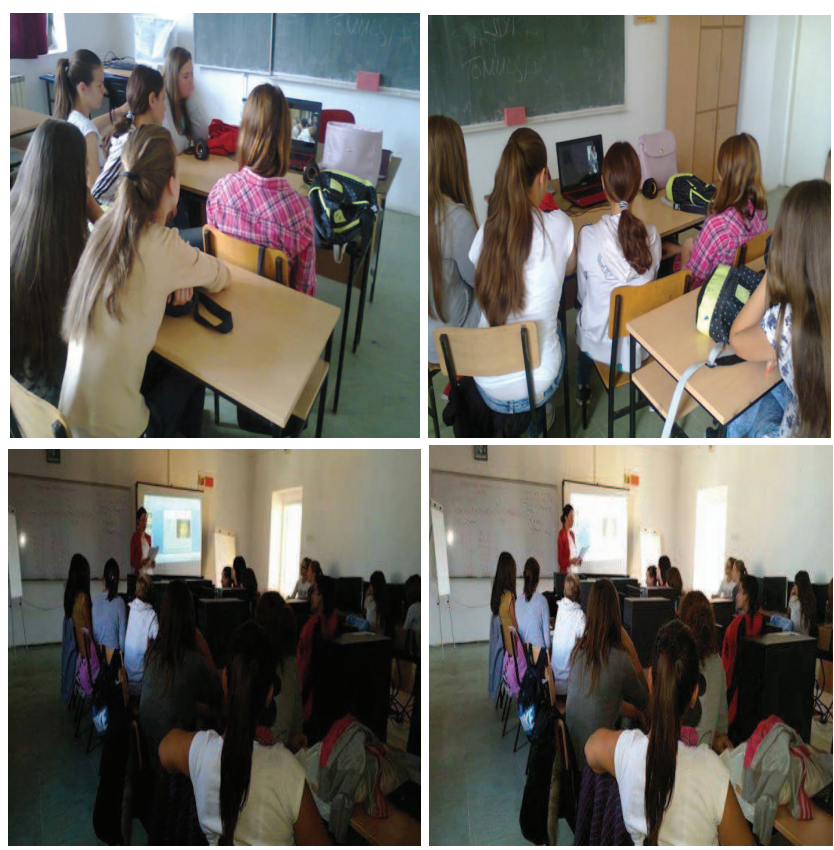

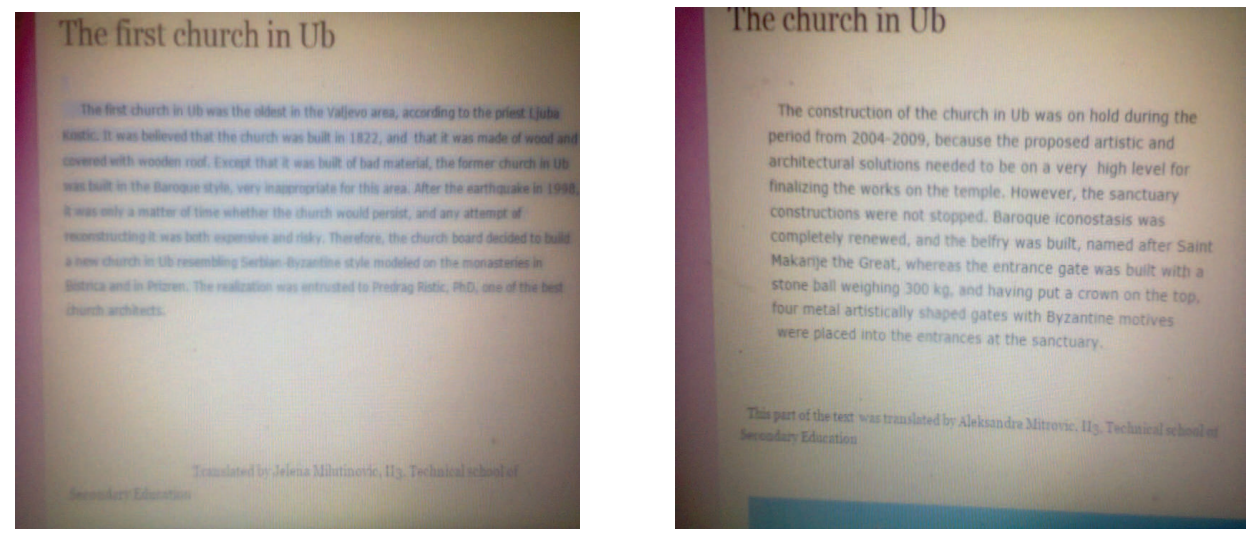

- Games

- Blog

- Poetry

- Culture

- Video clips

- Lessons with native speakers

- Stereotypes

- Role play

English language teachers should pay attention to students' capacities, interests and then form their classroom activities. Some of my students adore Victorian era writers, so we organised a public reading extracts, and then we watched a mouvie. In an other class, some students were interested in history, kings and queens, so we made a family tree, and then watched "the King's Speech". One of the possible solutions may be lessons with native speakers, and my friend Philip, who is a teacher helps me motivate my students. One of my favourite lessons is the one dealing with stereotypes, and we form groups and make debates, so each student is engaged in the discussion. Students who love art can be inspired by a quote, some topic and they can do a painting. I gave them to choose the text they would like to translate about Ub, and the best texts were posted on the blog, and we made a presentation. Of course, the students should know what is expected from them, and when they perform successfully, they should be adequately rewarded and praised for their hard work. We must remember, the targets need to be clear to students and achievable. 
Learning is an ongoing process. Given of the fact that we have Information technologies on our disposal, we should try to use it in the learning process, so that we get positive results in most cases.

Ivana Prokic

Technical School "Ub"

\title{
THE WAYS OF SUCCESSFUL IMPLEMENTATION OF DIGITAL HUMANITIES INTO PEDAGOGY
}

\begin{abstract}
Summary
The aim of this paper is to show the significance of Pedagogy in the Field of Digital Humanities. There are different methods that teachers may use in order to enhance their students' vocabulary using new technologies. By visualization, we can incline them to imagine and guess the meaning, and then to work it out together just giving them instructions. I started implying this idea right after I had practiced it at the Elta seminar. According to Piaget (1958), assimilation and accommodation require an active learner, not a passive one, because problem-solving skills cannot be taught, they must be discovered. Their knowledge then becomes permanent.

I evaluated students' knowledge of the new vocabulary of the standardized tests that measure proficiency and achievement in the English language, and I was paying attention at the performance of learners at anytime of the learning process. I observed that students were not showing as much interest in my instructions as they were in the previous term. They started feeling that this new language is too difficult for them to learn. Some may even appear to regress and have difficulty in every part of language learning, such speaking, reading, pronunciation, vocabulary, grammar and understanding. Through Digital Humanities, this problem may be over passed successfully, but it takes some time. This idea struck me when I noticed that some of my students reached the Plateau effect. I gradually started introducing various topics, from culture, sports, history, films to literature. So, how can we achieve it?! Given of the fact that we live in the $21^{\text {st }}$ century, students have iPhones, which can be used for learning new words, finding useful information, etc. They may become motivated in the second language acquisition.
\end{abstract}

Key words: Digital Humanities, visualization, the Plateau effect, new vocabulary, second language acquisition 